\title{
Community structure and seasonal dynamics of diatom biofilms and associated grazers in intertidal mudflats
}

\author{
Emel Sahan ${ }^{1}$, Koen Sabbe ${ }^{2}$, Veronique Creach ${ }^{3,4}$, Guillermina Hernandez-Raquet ${ }^{1,5}$, \\ Wim Vyverman ${ }^{2}$, Lucas J. Stal ${ }^{3}$, Gerard Muyzer ${ }^{1, *}$ \\ ${ }^{1}$ Department of Biotechnology, Delft University of Technology, Julianalaan 67, 2628 BC Delft, The Netherlands \\ ${ }^{2}$ Laboratory of Protistology \& Aquatic Ecology, Department of Biology, Ghent University, Krijgslaan 281-S8, \\ 9000 Ghent, Belgium \\ ${ }^{3}$ Netherlands Institute of Ecology (KNAW-NIOO-CEME), Postbus 140, 4400 AC Yerseke, The Netherlands \\ ${ }^{4}$ Present address: Centre for Environment, Fisheries \& Aquaculture Science (CEFAS), Pakefield Road, Lowestoft, \\ Suffolk NR33 0HT, UK \\ ${ }^{5}$ Present address: INRA, UR050, Laboratoire de Biotechnologie de l'Environnement, Narbonne, France
}

\begin{abstract}
The composition and seasonal dynamics of biofilm-associated eukaryotic communities were analysed at the metre and kilometre scale along a salinity gradient in the Westerschelde estuary (The Netherlands), using microscopy and a genetic fingerprinting technique (PCR-DGGE). Microphytobenthic biomass, measured as chlorophyll a ( $\mathrm{chl} \mathrm{a}$ ), varied seasonally over 2 orders of magnitude, being highest in spring. Communities were dominated by epipelic diatoms, in particular by members of the genus Navicula. In spring, a few smaller epipelic diatom species dominated during biomass peaks, while during the rest of the year, communities were more diverse and were characterised by larger species. The microphytobenthic community collapsed when grazers appeared, which happened concomitantly with a rise in temperature. Spring biomass development was associated with marked changes in porewater nutrient concentrations, especially towards the estuary mouth. In the DGGE data, diatoms, ciliates, amoebae, copepods, nematodes, annelids and platyhelminthes were detected. Ordination analysis of the species counts and DGGE data were largely congruent and indicated that on the scale of the whole estuary (i.e. km scale), taxonomic turnover in microphytobenthos composition was mainly associated with the salinity gradient. At smaller spatial scales, the position of sampling localities along the tidal exposure gradient appeared to be the main determinant of species turnover, in particular in the brackish reaches of the estuary.
\end{abstract}

KEY WORDS: Epipelic diatoms · Eukaryotes · Intertidal mudflat · Salinity gradient · Seasonal dynamics Resale or republication not permitted without written consent of the publisher

\section{INTRODUCTION}

Intertidal mudflats are known as highly productive areas that may contribute up to $50 \%$ of the primary production of estuaries (e.g. Underwood \& Kromkamp 1999). In these sediments, epipelic diatoms form the base of the food web (Admiraal et al. 1984b, Underwood et al. 1998). These diatoms form a biofilm on the sediment surface. Benthic diatoms produce copious amounts of extracellular polymeric substances (EPS) (e.g. Stal 2003 and references therein), which are considered to render stability to the sediment by increasing the erosion threshold (e.g. Decho 2000). Microphytobenthos is an important food source for micro-, meio- and macrobenthic organisms and for bacteria (e.g. Heip et al. 1995, Middelburg et al. 2000, de Deckere et al. 2001).

Estuaries and their intertidal sediments experience large fluctuations in hydrological, morphological and chemical conditions. This may drive changes in the 
diversity and structure of the biofilm communities. Some species seem to be limited to a narrow habitat, while others tolerate a much wider range of environmental variations. Besides their distribution along the gradients in the estuary, organisms in the sediment also show distinct seasonal variations, while the situation may also differ from year to year. These relate to changes and variations in temperature, irradiance, river discharge etc. Last but not least, predation and competition are also factors that influence community composition and structure.

The vast majority of studies on the structure of benthic diatom communities are based on microscopic observations of acid-cleaned sediment samples (e.g. Sabbe 1993, Thornton et al. 2002, Haubois et al. 2005). This approach has limitations. Not only is it time consuming and requires detailed knowledge of the taxonomy of these organisms but, more importantly, it does not permit one to distinguish between empty frustules and living cells. Frustules of dead benthic diatoms may remain present in the sediment for prolonged periods, and silty sediments often contain many frustules of sedimented planktonic forms. This may interfere with the detection of detailed seasonal and spatial patterns in community composition and diversity of the biofilm-forming diatoms. Molecular biological techniques allow the processing and comparison of large number of samples in a short time (Muyzer et al. 1993). An additional advantage lies in the possibility to assess diversity and community composition of notoriously difficult-to-study groups of organisms, e.g. ciliates and flagellates. A number of papers that studied diversity of eukaryotes by using the small subunit ribosomal RNA genes (i.e. the $18 \mathrm{~S}$ rRNA gene or the 16S rRNA gene of the chloroplast) showed the enormous diversity present in different environments (e.g. Diez et al. 2001, Massana et al. 2002, Stoeck \& Epstein 2003, Lawley et al. 2004). Only a few studies combined microscopy and genetic fingerprinting techniques in order to study the phytoplankton communities in the Bay of Fundy and in the solar salterns of Bras del Port (e.g. Estrada et al. 2004, Savin et al. 2004). To date, however, this approach has not been applied to estuarine or marine microbenthic communities.

The aim of the present study was to investigate the changes in the spatial structure and the seasonal dynamics of diatom biofilms and associated grazer communities along a salinity gradient in the Westerschelde estuary and to determine the environmental parameters that control them. We applied both lightmicroscopical analysis and denaturing gradient gel electrophoresis (DGGE) of PCR-amplified 18S rRNA gene fragments in order to evaluate discrepancies, congruence and potential complementarities between both marker sets. Ordination techniques were used to relate the observed species or DGGE bands to environmental variables.

\section{MATERIALS AND METHODS}

Site description and sampling. Three different sites in the Westerschelde estuary, i.e. Appelzak (A), Biezelingsche Ham (B) and Paulina polder (P), with average salinities of $5.4,17.6$ and $20.4 \%$, respectively, were selected for measurements (see Fig. 1). Appelzak and Biezelingsche Ham were sampled at a high- (1) and at a mid-shore station (2), while Paulina polder was sampled at a mid-shore station only. The difference in emersion time between the high- and mid-shore stations ranged from 1.5 to $2.5 \mathrm{~h}$. Station positions were determined by GPS (geographical positioning system). Each location was sampled 9 times between April 2002 and September 2003. Sampling was done during low tide, between 10:00 and 14:00 h Detailed information on the physical and biological parameters of these sites

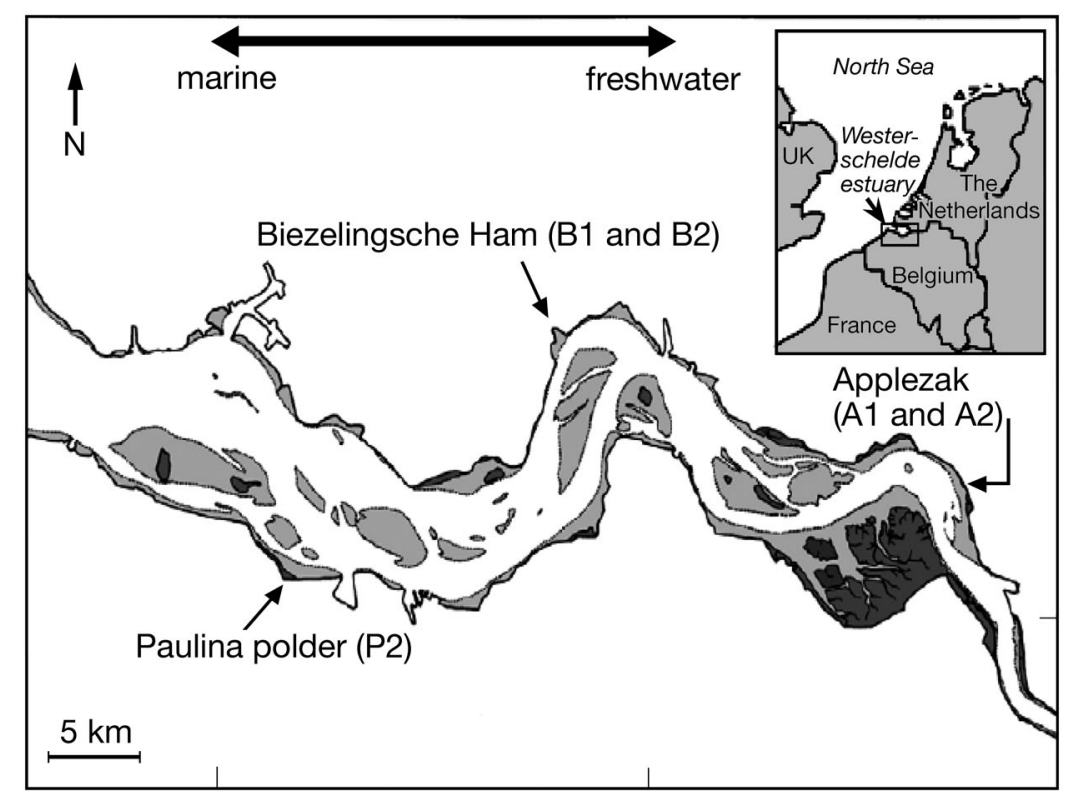

Fig. 1. Map of the sampling locations Appelzak (A), Biezelingsche Ham (B) and Paulina polder (P) in the Westerschelde estuary. The stations at each location are: high-shore A1 $\left(51^{\circ} 23^{\prime} 01^{\prime \prime} \mathrm{N}, 004^{\circ} 14^{\prime} 32^{\prime \prime} \mathrm{E}\right)$ and B1 $\left(51^{\circ} 26^{\prime} 40^{\prime \prime} \mathrm{N}\right.$, $\left.003^{\circ} 55^{\prime} 28^{\prime \prime} \mathrm{E}\right)$ and mid-shore A2 $\left(51^{\circ} 23^{\prime} 00^{\prime \prime} \mathrm{N}, 004^{\circ} 14^{\prime} 19^{\prime \prime} \mathrm{E}\right), \quad \mathrm{B} 2$ $\left(51^{\circ} 26^{\prime} 36^{\prime \prime} \mathrm{N}, 003^{\circ} 55^{\prime} 43^{\prime \prime} \mathrm{E}\right)$ and P2 (51 $\left.21^{\prime} 07^{\prime \prime} \mathrm{N}, 003^{\circ} 43^{\prime} 45^{\prime \prime} \mathrm{E}\right)$ 
can be found in Forster et al. (2006). More general information about the intertidal benthic ecosystems of the Westerschelde estuary can be found in Meire et al. (2005) and Baeyens et al. (1998).

Surface sediment samples (i.e. the upper $2 \mathrm{~mm}$ ) were taken using a 'contact corer' by freezing the sediment surface through a metal disk that contains liquid nitrogen (Ford \& Honeywill 2002). At each station, 5 replicate samples were taken within $5 \mathrm{~m}$ of the GPS location. Samples were used for determination of microphytobenthic chlorophyll a ( $\mathrm{chl}$ a), water content and for DNA extraction. In order to reduce the total number of samples for analysis, we only used the replicate samples with the highest chl a values for the PCRDGGE. Preliminary analyses (not shown) revealed that the high chl a samples compared well with the other replicates containing less chl $a$, with differences being much lower than those among samples from different locations and/or sampling periods. For grain size analysis and microscopy, replicate samples were pooled. Porewater was obtained by centrifugation $\left(10 \mathrm{~min}\right.$ at $2500 \mathrm{rpm}[1000 \times \mathrm{g}]$ at $\left.10^{\circ} \mathrm{C}\right)$; the supernatant was filtered $(\mathrm{GF} / \mathrm{F})$ and frozen $\left(-20^{\circ} \mathrm{C}\right)$ until further chemical analyses.

Environmental parameters. The shore heights of the stations were determined by reference to a digital elevation model of the estuary and confirmed by direct observation of the timing of emersion and immersion periods. Sediment surface temperatures were measured with an electronic thermometer at each sampling occasion. The mean irradiance at all sites was recorded at hourly intervals during 2002 and 2003 using a Licor Li-192 sensor.

For chl a measurements, the samples were freezedried and stored at $-80^{\circ} \mathrm{C}$ until analysis. Pigments were extracted with $90 \%$ (v/v) acetone from aliquots of $100 \mathrm{mg}$ of freeze-dried sediments. Mechanical disruption using $1 \mathrm{~mm}$ beads in a BeadBeater for $20 \mathrm{~s}$ ensured an efficient release of pigments. Acetone extracts were quantified using HPLC (Rijstenbil 2003). $\mathrm{NO}_{2}{ }^{-} \mathrm{N}$, $\mathrm{NO}_{3}{ }^{-}-\mathrm{N}, \mathrm{NH}_{4}{ }^{+}-\mathrm{N}$ and $\mathrm{PO}_{4}{ }^{3-}-\mathrm{P}$ were measured using standard colorimetric techniques (Grasshoff 1976) on a SKALAR SA 4000 segmented flow analyser. Salinity was measured using a titration method with SAC 80 (Radiometer). The percentage of water was determined by the loss of weight of the sample after $48 \mathrm{~h}$ of freezedrying. Total organic carbon (TOC) was measured with an elemental analyser (Elementar, vario EL). Sediment grain size and silt content of the sediment were determined by granulometric analysis using a laser diffraction analyser (Malvern Mastersizer 2000).

Morphological identification of diatoms. Samples were oxidised with a 1:1 mixture of hydrogen peroxide (30\% [v/v]) and acetic acid (100\% [v/v]), rinsed several times with distilled water and mounted in Naphrax
(PhycoTech). Identifications and cell counts were made using a Leitz Diaplan microscope equipped with differential interference contrast (DIC). Identifications followed Sabbe (1997). Per sample ca. 300 diatom valves were counted (min. 277, max. 336), and relative abundances were calculated. Microscopic analyses of both live and glutaraldehyde-fixed specimens allowed assignment of species to 4 functional categories based on their mode of life: epipsammic, epipelic, tychoplankton and true plankton (Vos \& Dewolf 1993, Forster et al. 2006). Diatoms belonging to the epipsammic fraction (small species attached to sand grains) were not included in the present analyses as they were never abundant at the study sites (Forster et al. 2006). Previous analyses have shown that tychoplanktonic taxa (that occur both as benthic and pelagic diatoms) were most abundant (up to $40 \%$ ) when total community biomass based on chl a concentration was the lowest. As their exact life style is obscure and as it is not clear to what degree they contribute to the productivity of biofilms (or whether they mainly comprise nonactive or dead cells), we have also omitted them from the analyses. Likewise, the truly pelagic fraction, which mainly consisted of dead plankton cells that sedimented from the water column, was not included either. The focus of the present paper is therefore solely on the motile epipelic fraction, which makes up the bulk of community biomass in intertidal areas (see e.g. Herlory et al. 2004). Only epipelic species, which reach a relative abundance of $5 \%$ in at least 1 sample, were included in the analyses. The presence of valves belonging to rare species may be purely accidental and, hence, may seriously distort community and diversity analyses. Our analyses of patterns in distribution and diversity therefore only pertain to the fraction of the biofilm-forming epipelic species that makes up the bulk of the biofilm autotrophic biomass.

Biovolumes were calculated on the basis of the equations proposed by Hillebrand et al. (1999); these were then used to determine the relative contribution of each species to the total biovolume of the cells counted. The latter data were used in the ordination analyses and for the calculation of the diversity indices of the diatom data (see below).

Genetic fingerprinting analysis. DNA was extracted from 100 to $200 \mathrm{mg}$ of sediment sample using the Soil DNA Extraction kit (MoBio Lab) combined with vortexing at maximum speed for $10 \mathrm{~min}$. PCR was performed with the primers Euk1Af and Euk516r-GC, which amplify an approximately $560 \mathrm{bp}$ fragment of the 18S rRNA gene (Diez et al. 2001). PCR mixtures $(50 \mu \mathrm{l})$ contained 10 to $20 \mathrm{ng}$ of environmental DNA as template, each primer at a concentration of $0.5 \mu \mathrm{M}$, each deoxynucleoside triphosphate (dNTP) at $200 \mu \mathrm{M}$, $1.5 \mathrm{mM} \mathrm{MgCl}_{2}$ and $2.5 \mathrm{U}$ of Taq DNA polymerase (Qia- 
gen). Reactions were performed in a Biometra thermocycler with the following cycle: an initial denaturation of $95^{\circ} \mathrm{C}$ for $3 \mathrm{~min}, 25$ cycles of denaturation of $95^{\circ} \mathrm{C}$ for $45 \mathrm{~s}$, annealing at $60^{\circ} \mathrm{C}$ for $1 \mathrm{~min}$ and extension at $72^{\circ} \mathrm{C}$ for $1 \mathrm{~min}$, and a final extension at $72^{\circ} \mathrm{C}$ for $10 \mathrm{~min}$. PCR products were first analysed by agarose electrophoresis prior to DGGE analysis.

For DGGE, $6 \%$ polyacrylamide gels with a denaturant gradient from 20 to $50 \%$ were used for analysing the amplified DNA fragments. Approximately $300 \mathrm{ng}$ of PCR product was applied to each well. Electrophoresis was run at a constant voltage of $100 \mathrm{~V}$ for $16 \mathrm{~h}$ at $60^{\circ} \mathrm{C}$. Subsequently, the gels were stained with ethidium bromide and the results were visualised using the Gel Doc 1000 system (Biorad Laboratories). DGGE gel pictures were analysed using Phoretix 1D Pro in order to obtain a matrix containing the band percentage values of each sample as it was described in Massieux et al. (2004). These data were then used for the ordination analyses of the genetic fingerprinting data (see below). Major bands were excised from the gel, re-amplified and sequenced directly using the same primers. The partial sequences were aligned into an existing tree by using the ARB software package (Ludwig et al. 2004).

Data analysis. Ordination techniques were used to relate the microscopic analysis and genetic fingerprinting data to measured environmental variables. All analyses were performed with the software package CANOCO for Windows 4.5 (ter Blaak \& Smilauer 1998). The species data were log-transformed prior to analysis; the environmental data were re-standardised to zero mean and unit variance in the Canoci for Windows program. Detrended correspondence analysis (DCA) using detrending by segments was applied in order to determine the length of the gradient in the species and genetic fingerprinting data. Since these values never exceeded $3 \mathrm{SD}$ (standard deviation units of species turnover), we assumed that the species data only show a low degree of unimodality, in which case linear ordination methods are more appropriate to analyse the data (ter Braak \& Smilauer 2002). We therefore used the direct, linear method of redundancy analysis (RDA) to explore the relationships between the environmental variables and the species composition obtained by microscopic and genetic fingerprinting techniques. Forward selection procedures were used to select minimal sets of environmental variables that relate significantly to the variation in the species and genetic fingerprinting data. The statistical significance of each selected variable was judged by a Monte Carlo permutation test (199 permutations, significance level $p=0.05$ ). The remaining environmental variables were added as supplementary (or passive) variables, i.e. they were added post hoc to the existing RDA analyses by projection (i.e. regression onto the existing axes). The Shannon index (see below) and the measure of the average cell biovolume per sample and the relative abundance of epipsammon and tychoplankton were also included as supplementary variables.

The biomass contributions of the epipelic species and the DGGE percentage values were used to calculate species richness (total number of species: SR) and the Shannon index ( $H^{\prime}$, Magurran 1988) according to the program Primer 5 for Windows (ver. 5.2.2).

Microscopic count data were available for all sites and dates, except April 2002. DGGE data for all sites and dates were available, except B1 and B2, which were only for April and May 2002.

\section{RESULTS}

\section{Site characteristics}

Porewater salinity fluctuated between April 2002 and September 2003 at all 3 locations (Fig. 2A). Salinity was lowest in winter and early spring and highest in late summer at all stations. Although the lowest average salinities of $8.3 \pm 3.5$ and $9.3 \pm 5.8 \%$ o were observed at Stn A1 and A2, respectively, salinity increased sharply to $17 \%$ in September 2003, probably as a result of low riverine runoff. The salinities at $\mathrm{B}$ and $\mathrm{P}$ ranged from 14.4 to $29 \%$ in the period from April 2002 to September 2003. There were no pronounced differences in salinity between the mid- and high-shore stations. Surface temperature peaked (i.e. 20 to $22^{\circ} \mathrm{C}$ ) between July and September 2003, and was lowest in February 2003 $\left(4^{\circ} \mathrm{C}\right)$ at all locations (Fig. 2B). Average tidal exposure ranged between 11.5 and $17.7 \mathrm{~h} \mathrm{~d}^{-1}$, with lowest values at B2 and highest at A1 (Fig. 2C). Sediments were rather homogeneous at all sites. They comprised a large proportion of silty particles (average of $67.6 \%$ ) with an average median grain size of about $45.3 \pm$ $27 \mu \mathrm{m}$ and a high water content (average of $58.1 \%$ ) (Fig. 2D-F). Only in February 2003 did large fluctuations of these variables occurred at Stns A1 and A2, during which period the silt fraction was largely washed out. The TOC, $\mathrm{chl} a_{1} \mathrm{NH}_{4}{ }^{+}, \mathrm{NO}_{2}{ }^{-}$and $\mathrm{PO}_{4}{ }^{3-}$ peaked in spring, usually in April, at all stations (Figs. 2G \& 3A-E). While the highest average chl $a$ and TOC concentrations $\left(113.4 \mathrm{mg} \mathrm{m}^{-2}\right.$ and $2.5 \%$, respectively) were observed at A1, B1 showed the lowest average chl a (53.2 $\left.\mathrm{mg} \mathrm{m}^{-2}\right)$ and $\mathrm{P} 2$ the lowest average TOC values $(0.9 \%)$ (Figs. $2 \mathrm{G} \& 3 \mathrm{~A}) . \mathrm{NO}_{3}{ }^{-}$showed the highest concentrations in February at $\mathrm{A} 1$ and $\mathrm{A} 2$; however, at $\mathrm{B} 1, \mathrm{~B} 2$ and $\mathrm{P} 2$ the highest $\mathrm{NO}_{3}{ }^{-}$concentrations were in March, April and May, respectively (Fig. 3B). The average $\mathrm{NH}_{4}{ }^{+}$and $\mathrm{NO}_{2}{ }^{-}$concentrations showed an increasing trend toward the estuary mouth (from 

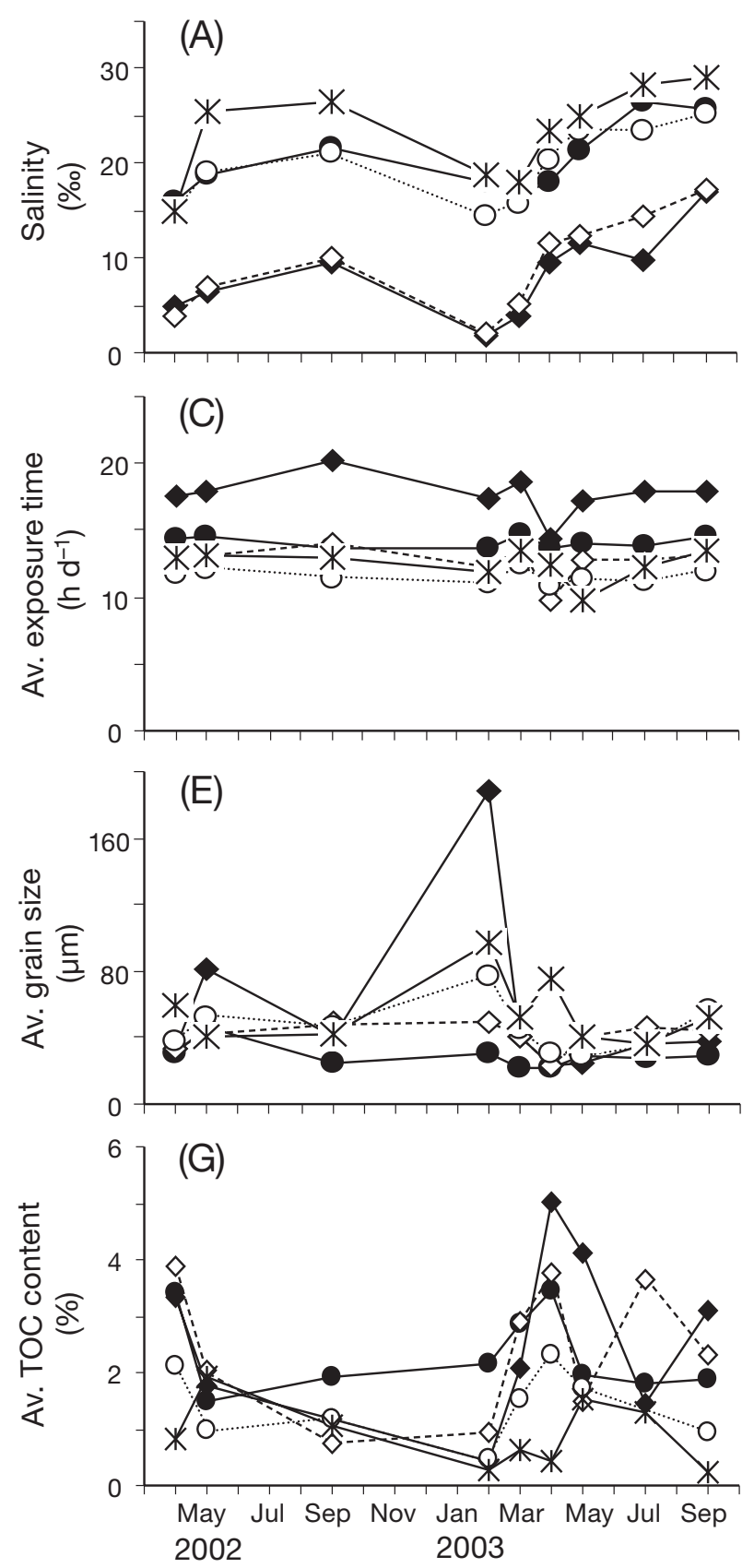
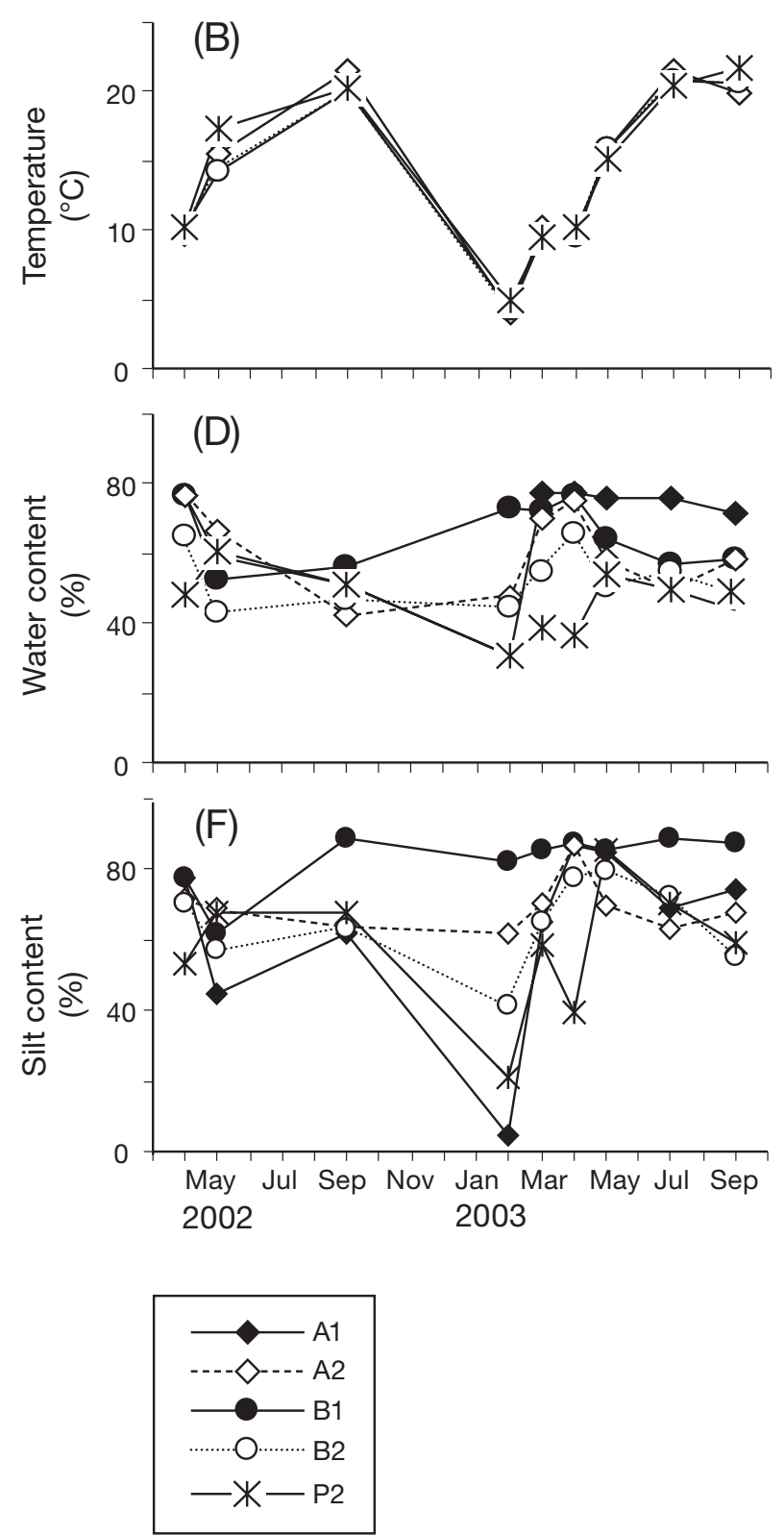

Fig. 2. Characteristics of the sediments at 3 different locations (A, B and P) in the Westerschelde between April 2002 and September 2003: (A) salinity, (B) temperature, (C) exposure time, (D) water content, (E) grain size, (F) silt content and (G) total organic carbon (TOC) content. Numbers next to the letters indicate the elevation of the sites: high-shore (1) and mid-shore (2)

119.6 $\mu \mathrm{M}$ at $\mathrm{A} 1$ to $232 \mu \mathrm{M}$ at P2 for $\mathrm{NH}_{4}{ }^{+}$and from 2.6 to $4.3 \mu \mathrm{M}$ for $\mathrm{NO}_{2}^{-}$) (Fig. 3C,D). Although the average $\mathrm{NO}_{3}{ }^{-}$concentration followed the same pattern from $83.9 \mu \mathrm{M}$ at $\mathrm{A} 1$ to $295.8 \mu \mathrm{M}$ at P2, the highest average value of $348.3 \mu \mathrm{M}$ was observed at $\mathrm{B} 1 . \mathrm{PO}_{4}{ }^{3-}$ peaked at B1 $(64.2 \mu \mathrm{M})$, but this nutrient did not show a clear trend among the sites, and concentrations ranged from 35.5 to $47.3 \mu \mathrm{M}$ (Fig. 3E).

\section{Morphological identification of diatoms}

While a total of 158 diatom taxa were identified, only 17 epipelic diatom species reached an abundance of $>5 \%$ in at least 1 sample. A complete list of these taxa can be found in Forster et al. (2006, their Fig. 2). The genus Navicula was most abundant and was represented by $N$. arenaria var. rostellata, $N$. flanatica, 

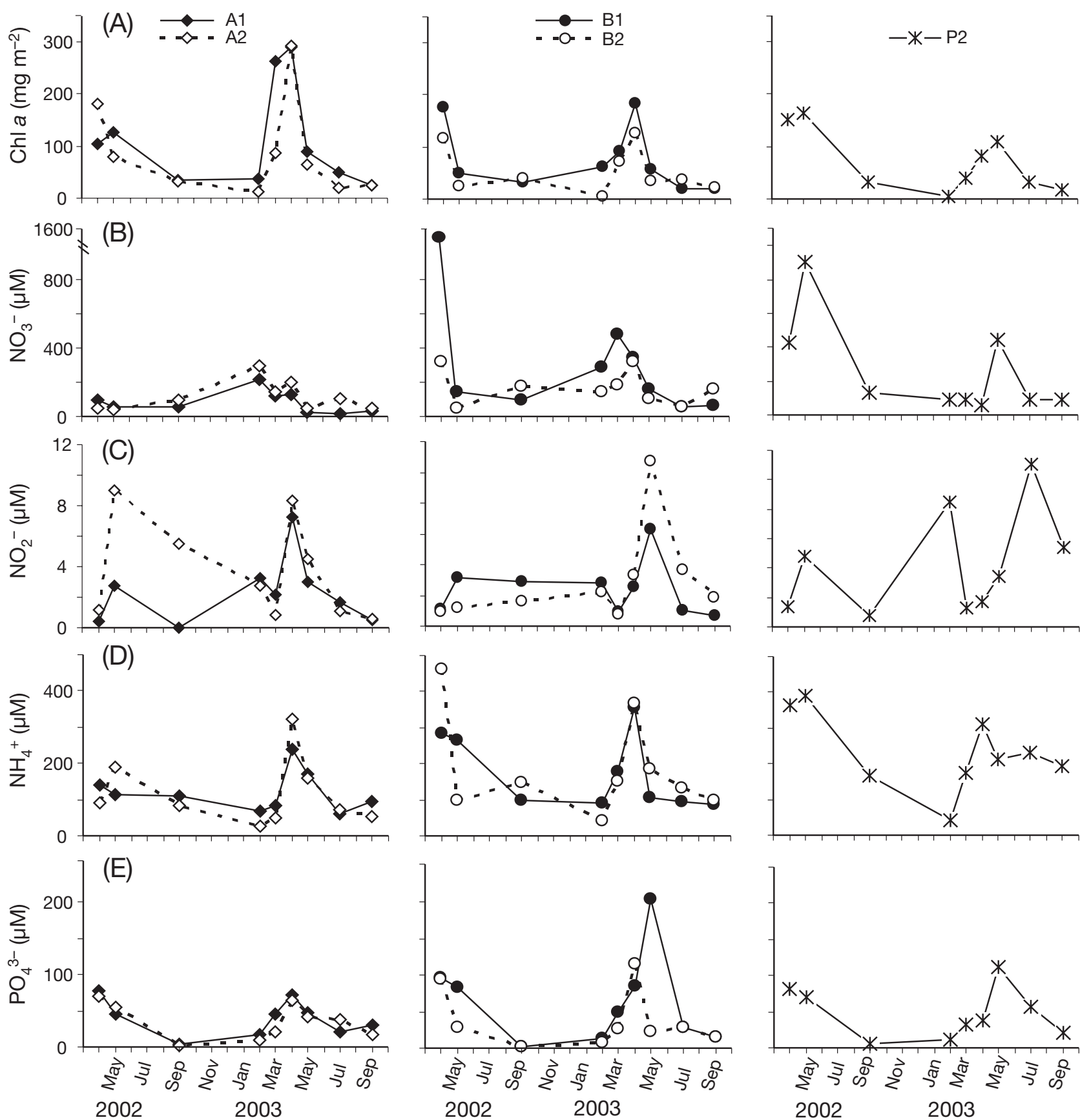

Fig. 3. (A) Sediment chl a (mg m${ }^{-2}$ ), (B) $\mathrm{NO}_{3}{ }^{-}$, (C) $\mathrm{NO}_{2}{ }^{-}$, (D) $\mathrm{NH}_{4}{ }^{+}$and (E) $\mathrm{PO}_{4}{ }^{3-}$ concentrations in the porewater of the sediment at 3 different locations (A, B and P) between April 2002 and September 2003. Numbers next to the letters indicate the elevation of the sites: high-shore (1) and mid-shore (2)

N. gregaria, N. phyllepta and some unidentified species. In addition, members of the genera Amphora, Gyrosigma and Staurophora were also present in the samples. At none of the sites did a single species dominate the diatom community. N. phyllepta and $N$. perminuta were the only species found at all sites, but usually in low abundance. RDA captured about $25 \%$ of the total variation in the species data along the first 2 axes (Fig. 4). The composition of epipelic diatoms appeared to be mainly related to the salinity gradient. The brackish sites $\mathrm{A} 1$ and $\mathrm{A} 2$, on the left-hand side of the diagram, were characterised by, e.g., Navicula flanatica, $N$. gregaria and Staurophora salina, while the marine stations (B1, B2 and P2, towards the right-hand side of 


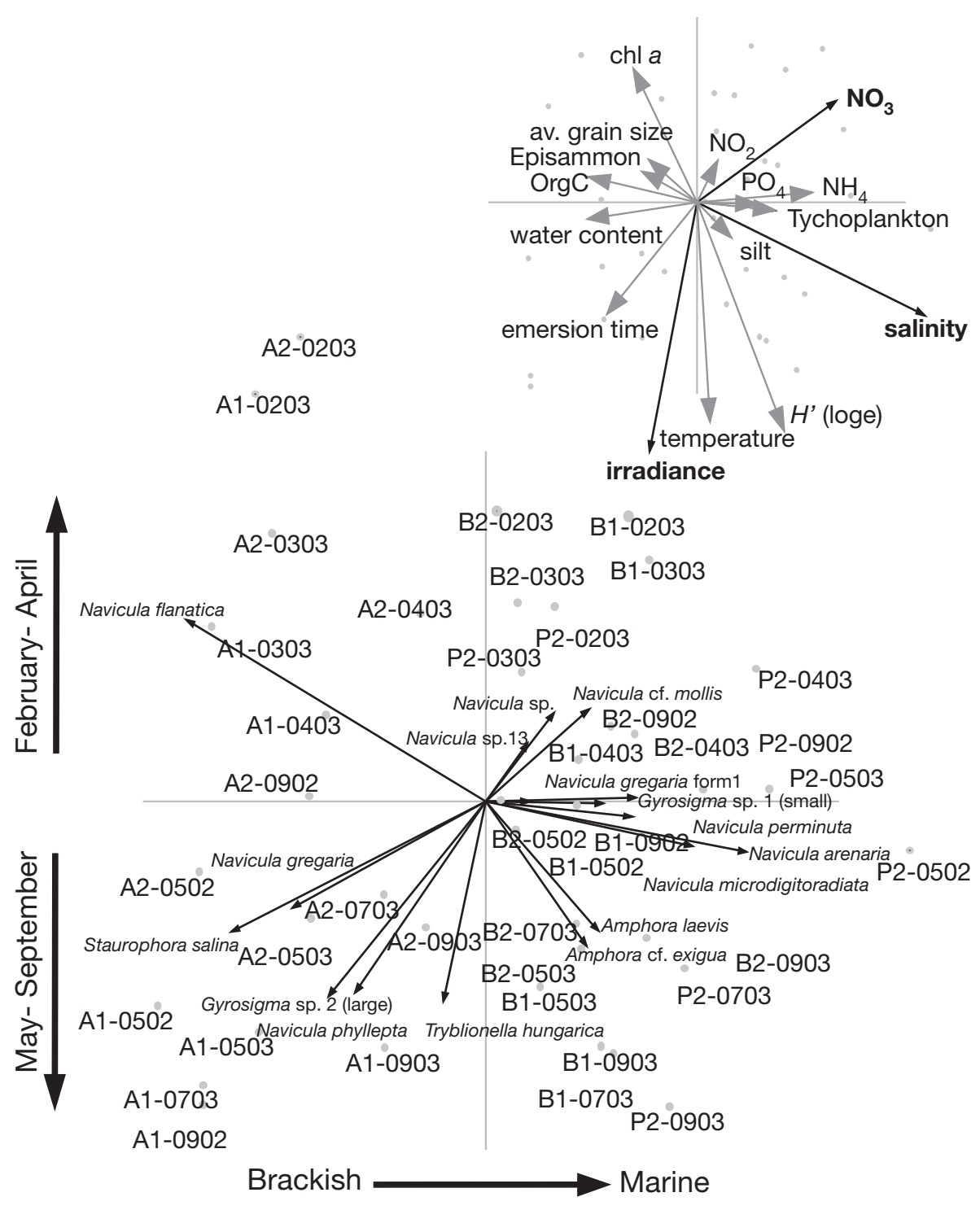

Fig. 4. Redundancy analysis (RDA) ordination diagram of the epipelic diatom count data for the sites Appelzak (A), Biezelingsche Ham (B) and Paulina polder (P). Numbers next to the letters refer to the elevation of the sites: high-shore (1) and mid-shore (2). Numbers to the right of the hyphen refer to the sampling month and year, respectively. Dots in both ordination diagrams refer to the sites. In the smaller ordination diagram, black arrows belong to the active environmental variables selected in the forward selection procedure; grey arrows are passive variables which do not actively contribute to the ordination. Two species names have been shortened to avoid crowding of the diagram, viz. Amphora laevis $=$ A. laevis var. laevissima and Navicula arenaria $=N$. arenaria var. rostellata. $H^{\prime}$ (loge based): Shannon index the plot) were related to species such as $N$. arenaria var. rostellata, $N$. microdigitoradiata and $N$. perminuta (Fig. 4). Along the second RDA axis, the early spring samples (February until April) of all stations were separated from the samples taken in late spring to summer (May until September). The early spring samples were characterised by high chl a values, lower diversity and a smaller average cell size. This early spring bloom was dominated by $N$. flanatica in the brackish stations A1, A2 and B2, by Navicula sp. 13, Navicula sp. and Gyrosigma sp. 1 in Stn B1 and by N. arenaria var. rostellata and Gyrosigma sp. 1 in the marine station P2. In May, the diatom community collapsed at all stations (Figs. 3 \& 5), became more diverse and contained larger species. In the brackish stations, N. gregaria, N. phyllepta, Staurophora salina and Gyrosigma sp. 2 became dominant, while at the marine sites of the estuary Amphora spp., Navicula microdigitoradiata and Petrodictyon gemma became important. Forward selection of the environmental variables revealed that only salinity, nitrate and irradiance related significantly to the variation in the species data. Nitrate, nitrite, ammonia and phosphate values were on average higher at the marine sites, especially during the early spring bloom.

\section{DGGE profiles of the eukaryotic community}

DGGE analysis of the 18S rRNA gene fragments obtained by PCR amplification from the different seasonal samples of high- and mid-shore stations at 3 different sites (A, B and P) yielded 43 unique bands. The number of bands per sample (i.e. 'richness') ranged from 9 to 21. Although there were variations in the 


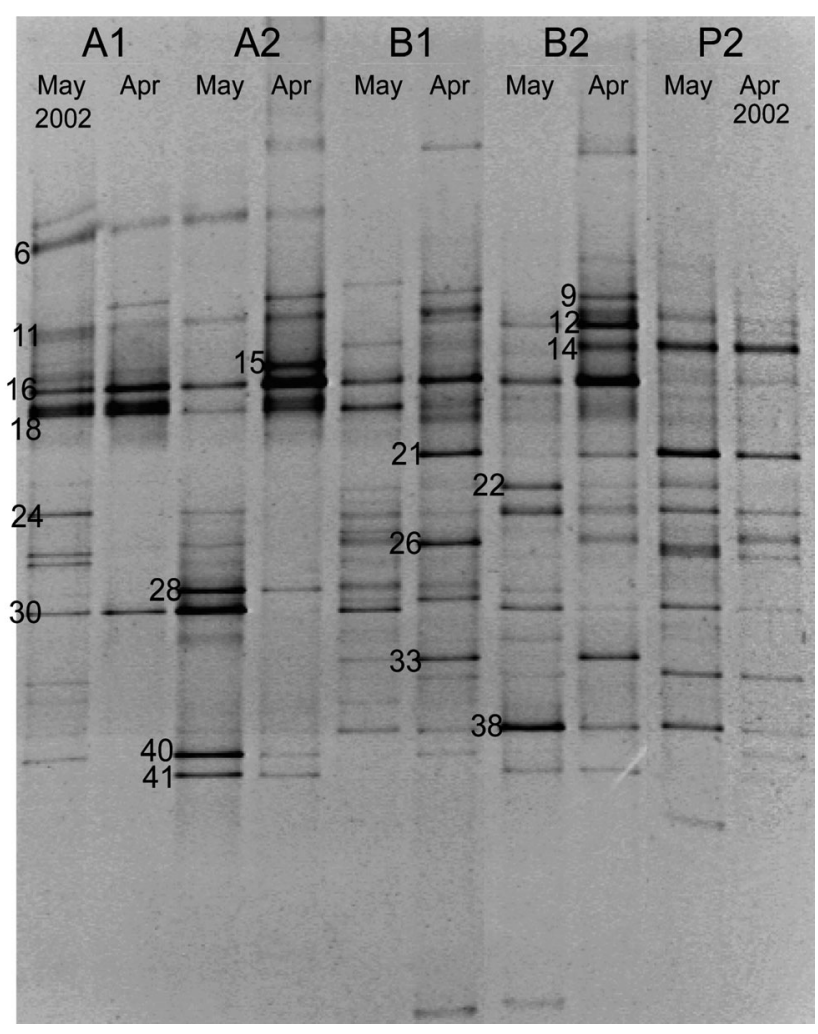

Fig. 5. Denaturing gradient gel electrophoresis (DGGE) patterns of the samples from 3 different locations in April and May 2002. Numbers next to the letters indicate the elevation of the sites: high-shore (1) and mid-shore (2) richness, there was no trend that explained the distribution of bands spatially or temporally. Out of 43 bands, 18 were successfully sequenced. However, for each sample, these sequenced bands covered $88 \%$ of the total band percentage values. DGGE band patterns (Fig. 5) and sequence information from excised bands and their similarities with sequences in the ARB database (Ludwig et al. 2004) are shown in Table 1. The sequences obtained were related to different taxa of benthic diatoms, protozoans and metazoans. The percentage similarities with closest relatives in the ARB database, especially with benthic animals, were low, and the phylogenetic affiliation of the observed bands could not therefore be resolved below the genus level for diatoms or phylum level for meio- and macrofauna.

All microphytobenthic representatives in the DGGE analysis belonged to the raphid pennate diatoms: the genera Navicula (Bands 11, 14 and 16) (Table 1, Fig. 5), Entomoneis (including its synonym Amphiprora) (Bands 18 and 21), Dickieia (Band 6) and Pleurosigma (Band 15), all of which have been commonly reported from the epipelon of intertidal sediments. Given the fact that Amphiprora/Entomoneis is phylogenetically closely related to Amphora (Medlin \& Kaczmarska 2004), Pleurosigma to Gyrosigma (Round et al. 1990) and Dickieia to Staurophora (Mann 1994), it is likely that the DGGE band sequences pertain to the same dominant organisms that were observed in the cell counts. The diatom bands were all located

Table 1. Identities of DGGE bands that were excised from the PCR products of the samples from the locations Appelzak (A), Biezelingsche Ham (B) and Paulina polder (P). Similarity percentages are according to the ARB database (2004)

\begin{tabular}{|lrlllc|}
\hline Band No. & Stn & Closest relative (Accession No.) & Phylum/Genera & Similarity (\%) & Accession No. \\
\hline Stramenophiles & & & & \\
WS_EUK6 & A1 & Dickieia ulvacea (AY485462) & Bacillariophyta/Dickieia & 94 & EF041834 \\
WS_EUK11 & A1 & Navicula phyllepta (AY485456) & Bacillariophyta/Navicula & 100 & EF041826 \\
WS_EUK14 & B2 & Navicula lanceolata (AY485484) & Bacillariophyta/Navicula & 100 & EF041836 \\
WS_EUK15 & A1 & Pleurosigma intermedium (AY485489) & Bacillariophyta/Pleurosigma & 98 & EF041831 \\
WS_EUK16 & A1 & Navicula sp. (AY485460) & Bacillariophyta/Navicula & 99 & EF041827 \\
WS_EUK18 & A1 & Amphiprora alata (AY485497) & Bacillariophyta/Amphiprora & 98 & EF041835 \\
WS_EUK21 & B1 & Entomoneis cf. alata (AY534908) & Bacillariophyta/Entomoneis & 80 & EF041843 \\
Protozoans & & & & \\
WS_EUK9 & B2 & Pseudomicrothorax dubius (X65151) & Alveolata/Ciliophora & 90 & \\
WS_EUK12 & B2 & Apusomonas proboscidea (L37037) & Apusozoa/Apusomonadida & 92 & EF041838 \\
Metazoans & & & & 91 & \\
WS_EUK22 & B1 & Aphrodite aculeata (AAZ83749) & Annelida/Phyllodocia & EF041830 \\
WS_EUK24 & A1 & Arrawaria sp. (ASP243677) & Platyhelminthes/Rhabdocoela & 87 & EF041832 \\
WS_EUK26 & B1 & Pontonema vulgare (AF047890) & Nematoda/Enoplida & EF041840 \\
WS_EUK28 & A2 & Cancrincola plumipes (L81938) & Arthropoda/Harpacticoida & 94 & EF041839 \\
WS_EUK30 & A1 & Pristina longiseta (AF411875) & Annelida/Haplotaxida & 100 & EF041841 \\
WS_EUK33 & B1 & Atriofonta polyvacuola (AF102895) & Platyhelminthes/Acoela & 65 & EF041842 \\
WS_EUK38 & B1 & Daptonema procerus (AF047889) & Nematoda/Monhysterida & 93 \\
WS_EUK40 & A2 & Meara sp. (AF051328) & Platyhelminthes/Nemertodermatida & 90 & EF041829 \\
WS_EUK41 & A2 & Tigriopus californicus (AF363306) & Arthropoda/Harpacticoida & 92 & EF041833 \\
& & & & EF041828 \\
\hline
\end{tabular}




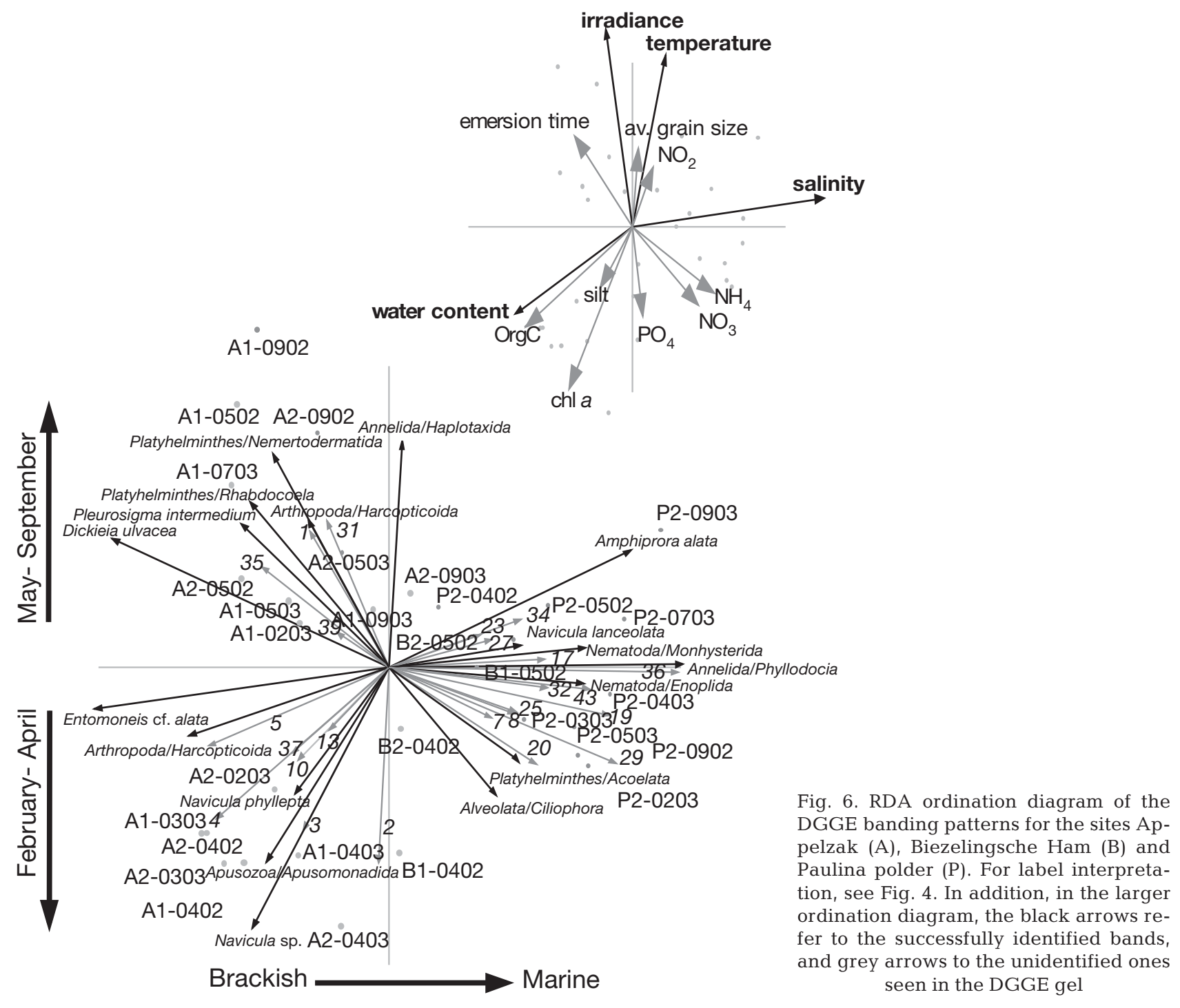

at the top part of the DGGE gels, indicating a lower melting point behaviour. Apart from 2 protozoan sequences, related to a ciliate (phylum Alveolata) (Band 9) and an apusozoan flagellate (phylum Apusozoa) (Band 12), all other sequences belonged to metazoans related to the phyla Platyhelminthes (Bands 24, 33 and 40), Annelida (Bands 22 and 30), Arthropoda (harpacticoid copepods) (Bands 28 and 41) and Nematoda (Bands 26 and 38), albeit mostly with low sequence similarities (about $90 \%$ or below; Table 1 ).

RDA of the DGGE band percentages (Fig. 6) captured about $30 \%$ of the variation in the data along the first 2 axes. In total, $42 \%$ of the variation in the phylotype data related significantly to the 4 environmental variables selected by the forward selection procedure, namely salinity, irradiance, temperature and water content of the sediment. As was the case for the diatom counts, the DGGE band patterns were related to salin- ity with the brackish sites A1 and A2 on the left-hand side of the diagram and the marine sites on the right. RDA Axis 1 was also significantly related to the water content of the sediment. Sequences of bands characteristic of the brackish sites were affiliated with the diatom genera Entomoneis (Amphiprora, cf. remark above), Navicula, Dickieia and Pleurosigma, the copepod genera Cancrincola and Tigriopus, the apusozoan flagellate and representatives of the Plathyhelminthes. Marine sites contained the diatom genera Navicula and Entomoneis (Amphiprora), a ciliate, 2 nematodes and 1 representative of both the Annelida and Plathyhelminthes. Similar to the results of the microscopical counts, the second axis separated the early spring samples (February, March and April), characterised by the dense diatom communities (i.e. high chl a values), from the other samples. This scatter was most pronounced at the brackish sites A1 and A2, with early spring being 


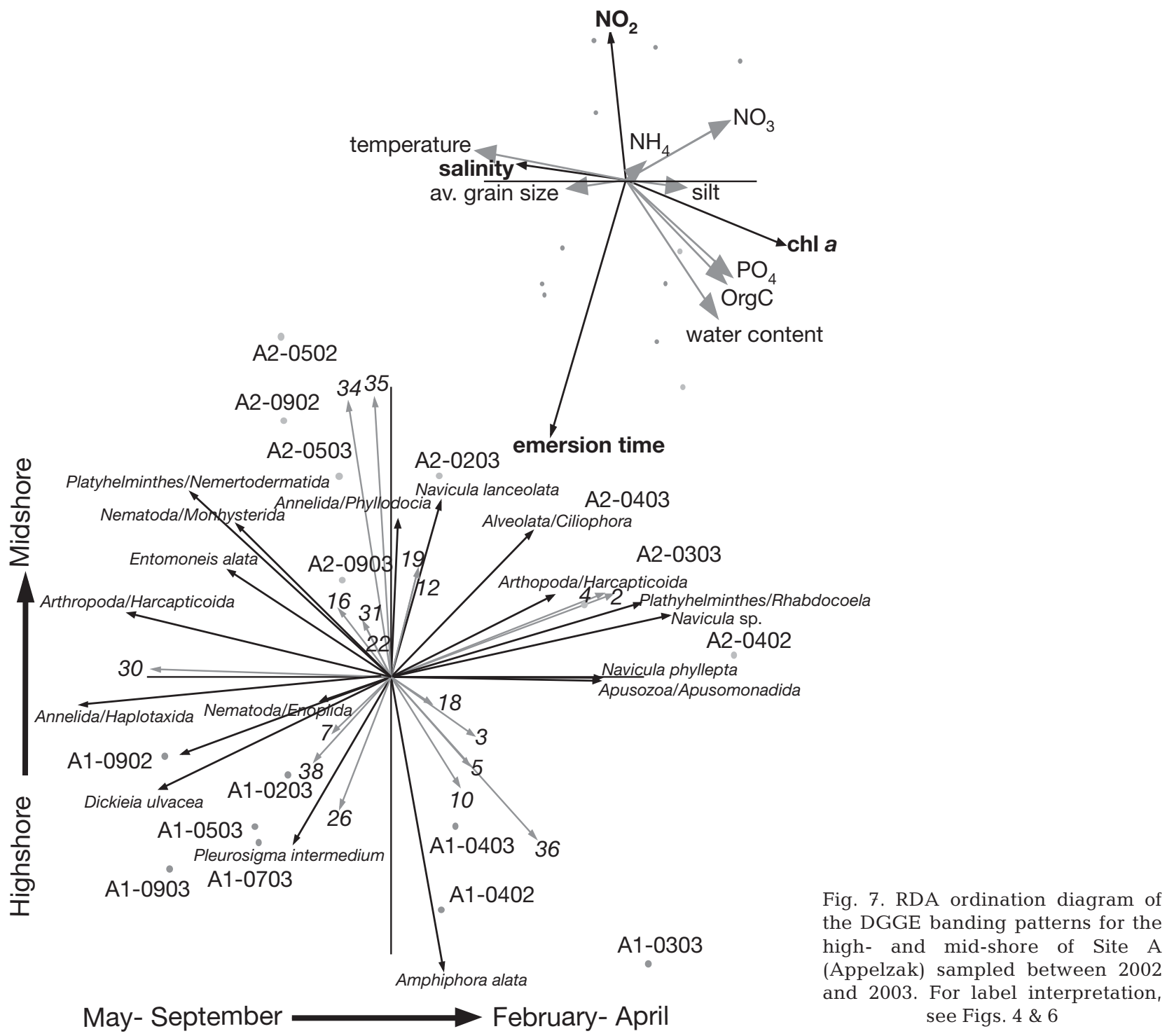

characterised by several diatom taxa and the apusozoan flagellate and late spring and summer samples being characterised mainly by several metazoan sequences (Fig. 6). Differentiation between the early and late spring samples at the marine site P2 was much less pronounced (Fig. 4), which is also evident from the DGGE band patterns (Fig. 5).

In order to assess the possible effects of tidal elevation, we separately analysed the data for the Appelzak site (the only transect for which a complete data set was available). The difference in emersion time between the high- and mid-shore stations of Appelzak was, on average, $2.5 \mathrm{~h}$. This RDA analysis, which captures about $40 \%$ of the DGGE band data along the first 2 axes, confirmed the strong differentiation between the early spring samples on the one hand and the late spring and summer samples on the other hand (RDA Axis 1; Fig. 7). Early spring samples had higher chl a values (diatom bloom, cf. Fig. 3) and lower salinities, and were mainly characterised by diatom and protozoan sequences. Metazoan organisms (meiobenthos [nematodes and copepods] and macrobenthos [annelids and flatworms]) were mainly characteristic of the late spring and summer samples. Along the second axis, there was a clear separation between the samples from the high-shore (A1) and the mid-shore (A2), with mid-shore samples having significantly higher nitrite values. There were distinct differences in both diatom and zoobenthic compositions between both sites throughout the year. 


\section{DISCUSSION}

Algal biomass at the surface of intertidal sediments in the Westerschelde varied from 5 to $292 \mathrm{mg} \mathrm{chl} \mathrm{a}$ $\mathrm{m}^{-2}$. These values are within the range of those published for similar systems (e.g. Underwood \& Kromkamp 1999, Goto et al. 2000). At all sites, chl a was the highest in early spring; diatom biomass started to decline after April. In many studies a pronounced increase of biomass was recorded during spring and summer (e.g. de Jong \& de Jonge 1995, Mundree et al. 2003), but in other cases no clear seasonal pattern was found (e.g. Goto et al. 2000, Thornton et al. 2002). The microphytobenthic biomass increases in early spring in the Westerschelde are mainly driven by epipelic diatoms (Forster et al. 2006), confirming other studies (e.g. Underwood 1994, Underwood et al. 1998). Microscopy, PCR-DGGE and environmental data showed that the spring development of biofilm coincided with major shifts in the composition of biofilm species, the zoobenthos, as well as the nutrient environment.

\section{Community structure of epipelic diatoms and of zoobenthos}

Ordination analysis of the microscopical counts of epipelic diatoms showed a pronounced relationship between diatom community composition and the estuarine salinity gradient (cf. Admiraal et al. 1984b, Underwood 1994). Certain species appeared to be typical for the brackish stations, e.g. Navicula flanatica, N. gregaria, N. phyllepta, Gyrosigma sp. 2, Stauphora salina and Tryblionella hungarica, as they correlated negatively with salinity, which was also observed in other systems and confirmed by laboratory studies (Cox 1998, Underwood \& Provot 2000). Species that were characteristic for the marine sites in the Westerschelde estuary included, for example, Amphora spp., N. arenaria var. rostellata, $N$. microdigitoradiata, $N$. cf. mollis and $N$. perminuta. These diatoms seem to function best within a narrow range of salinity and were classified as true marine or salt tolerant. Hence, changes in salinity may affect the distribution of these organisms (e.g. Admiraal et al. 1984b, Underwood 1994). However, other studies have indicated that diatoms may exhibit a wide tolerance to salinity. For instance, Cox (1998) showed that the freshwater diatom $N$. gregaria grew well in seawater. However, it should be noted that, within a species, different strains may exhibit different salinity tolerances (e.g. Cox 1995, Underwood \& Provot 2000, Vanelslander et al. unpubl. data).

The ordination analysis of DGGE data was largely congruent with that of microscopic counts and indi- cated that salinity, water content and seasonal factors such as temperature and irradiance were associated with patterns in the distribution of eukaryotic organisms, including epipelic diatoms and micro- and meiofauna, which is in agreement with earlier reports on the distribution of micro-, meio- and macrobenthic communities in the Westerschelde (e.g. Soetaert et al. 1995, Hamels et al. 2004, Ysebaert et al. 2005).

From the total of 43 DGGE bands, 18 were sequenced, 7 of which belonged to different types of epipelic diatoms. Using microscopy, 17 different species were found. PCR-DGGE does not detect genotypes if the abundance is $<1 \%$ (e.g. Muyzer et al. 1993). Hence, microscopic analysis may have a higher resolution. Using sequence similarity, diatoms could only be identified to the genus level and animals to the phylum level. This was mainly due to the poor representation of 18S rRNA gene sequences in the public databases. Nevertheless, the diatom count data and the DGGE agreed well. The affiliations obtained from DGGE sequences, Entomoneis (Amphiprora), Pleurosigma and Dickieia, are phylogenetically closely related to Amphora (Medlin \& Kaczmarska 2004), Gyrosigma (Round et al. 1990) and Staurophora (Mann 1994), respectively. Therefore, we concluded that the DGGE bands most probably relate to the same type of organisms as those observed by microscopy.

Analyses at the metre scale, studied at the brackish site Appelzak, show that in addition to the seasonal effect (RDA Axis 1, see below) there is also a strong relationship between phylotype composition and emersion time (RDA Axis 2; Fig. 7). The compositions in high- (A1) and mid-shore (A2) samples were different according to the elevations of the sampling sites. In addition, the high-shore (A1) was characterised by higher chl a concentrations. Several other studies pinpointed the importance of emersion/immersion on the algal biomass and species compositions (Oppenheim 1991, Underwood 1994, Brotas et al. 1995, Goto et al. 2000). Likewise, a clear relationship between exposure times and pigment in different brackish stations in the Westerschelde was observed by Ysebaert et al. (2005). Because the diatoms receive more light at the highshore level, they could eventually achieve higher production. The elevation of the sampling sites may therefore also be important for the distribution of the benthic fauna (Ysebaert et al. 2005).

\section{Dynamics of epipelic diatoms and of zoobenthos}

The diversity, composition and size of the epipelic diatoms varied between early spring and late spring/ summer, with a pronounced shift to higher diversity with larger types of diatoms during late spring and 
summer, particularly at the marine sites. Likewise, there was a concomitant shift in the size spectrum of the heterotrophs. Protozoa were only detected in the early spring samples, while the larger sized faunal forms dominated the communities during late spring and summer. Fluctuations of environmental conditions were more pronounced in early spring, especially at the brackish site. Hence, organisms present at these sites during such periods need to be flexible and able to adapt quickly to changing conditions. The more diverse community that was found during late spring and summer, especially at the marine site, could be the result of more stable environmental conditions. Likewise, the difference in size of the prevailing diatoms may be explained in terms of coping with the fluctuations in the environmental conditions in the Westerschelde. R-types, small and fast-growing species (Snoeijs et al. 2002) using an abundance of available resources in early spring time, are assumed to be less specialised than K-types, large and slow-growing species, under the limited resources that prevail in summer time. Therefore, large species may respond negatively to fluctuations in the spring time and appear in summer under stable conditions. Moreover, the presence of small or large species over the year would also be strongly affected by the type of grazers (e.g. Fenchel \& Kofoed 1976, Admiraal 1977). Similar to our DGGE data, Ysebaert et al. (2005) showed that in April the benthic community at the oligo/brackish sites was dominated by small animals, e.g., meiobenthos, copepods and nematodes, while in September larger animals, e.g., polychaeates and crustaceans were dominant.

The RDA analysis suggests that seasonal shifts of the epipelic diatom community are strongly influenced by light intensity and temperature. Many studies emphasised the correlation of chl a and changes in community composition with irradiation (e.g. Rasmussen et al. 1983, Brotas et al. 1995), although the grazer community may also have an effect (Hillebrand 2005). Light would most likely affect growth of the diatoms, while temperature may alter the activity of heterotrophs. At low temperature, the slow metabolism of benthic animals would prevent them from taking advantage of increased production by diatoms. Subsequently, when temperature increases, grazing pressure will increase, causing a breakdown of the diatom community. Similar observations were made for phytoplankton communities (Findlay \& Watling 1998). Most of the studies showed that algal biomass is regulated by top-down as well as bottom-up processes (e.g. Carpenter et al. 1985, Worm et al. 2002). While grazers limit the algal standing stock, light and nutrients regulate the biomass and productivity (e.g. Connor et al. 1982). Since the nutrients were present in excess, primary produc- tion and biomass in the Westerschelde was limited by light (van Spaendonk et al. 1993, Kromkamp et al. 1995).

In addition to light intensity and temperature, nutrient concentrations also showed differences along the salinity gradient. Nutrient concentrations increased during early spring towards the mouth of the estuary. This might be related to the higher quality of organic matter (nutrient rich) and the increased metabolic activity of benthic animals. Among the nutrients, nitrate appeared to be particularly closely related to the distribution of Navicula sp. and N. cf. mollis at the marine sites. This is interesting because algae prefer ammonium or amino acids as nitrogen sources (e.g. Admiraal et al. 1987, Underwood et al. 1998). Most studies focused therefore on ammonium uptake (e.g. Admiraal et al. 1984a, Underwood \& Provot 2000). There are other reports showing that in nutrient-rich cold environments, nitrate is preferentially taken up by diatoms $>20 \mu \mathrm{m}$, even in the presence of ammonium (e.g. Lomas \& Gilbert 1999). Dortch (1982) showed that nitrate was the source of new production in marine phytoplankton. These observations coincide nicely with ours.

In summary, the community composition of diatom biofilms in the Westerschelde was controlled by salinity, when the whole estuary was considered (kilometre scale), while the tidal regime was instrumental at the local scale in the brackish sites (metre scale). The highest biomass of the biofilm was characterized by light in the absence of grazers. Cell number, abundance and size were different in early spring when the highest biomass was present, compared to the rest of the year. The loss of biomass and shift in the species composition were mainly caused by the benthic fauna, which was strongly influenced by the temperature and presence of diatoms.

Microscopy together with PCR-DGGE and ordination analysis using environmental variables proved to be a promising approach to the study of ecological and food web interactions in biofilms of the microphytobenthos. Although microscopy gave a more detailed view of the diatom community, it is less useful for algae that have fewer distinguishing morphological features (e.g. cyanobacteria, green algae). The increase of sequences of $18 \mathrm{~S}$ rRNA genes in publicly accessible databases would further increase the potential of molecular analyses for eukaryotic algae. The use of multiple primer sets could give a more representative picture of the communities. Although we used the $18 \mathrm{~S}$ rRNA gene to estimate diversity, more variable regions (e.g. the ribosomal internally transcribed spacer), group-specific primers, or certain functional genes are needed to obtain a better resolution of the genetic diversity. 
Acknowledgements. We thank Dr. R. M. Forster for providing the chl a data, and Udo van Dongen for his help during sampling. This study was supported by the Research Council on Marine Research (VLANEZO) subsidised by the FWONWO, Contract ALW 832.11.003, and by BOF Project GOA 01GZ0705 (Ghent University).

\section{LITERATURE CITED}

Admiraal W (1977) Experiments with mixed populations of benthic estuarine diatoms in laboratory micro-ecosystems. Bot Mar 20:479-485

Admiraal W, Laane R, Peletier H (1984a) Participation of diatoms in the amino-acid cycle of coastal waters-uptake and excretion in cultures. Mar Ecol Prog Ser 15:303-306

Admiraal W, Peletier H, Brouwer T (1984b) The seasonal succession patterns of diatom species on an intertidal mudflat-an experimental analysis. Oikos 42:30-40

Admiraal W, Riauxgobin C, Laane R (1987) Interactions of ammonium, nitrate, and d-amino acids and l-amino-acids in the nitrogen assimilation of two species of estuarine benthic diatoms. Mar Ecol Prog Ser 40:267-273

Baeyens W, van Eck B, Lambert C, Wollast R, Goeyens L (1998) General description of the Scheldt estuary. Hydrobiologia 366:1-14

Brotas V, Cabrita T, Portugal A, Serodio J, Catarino F (1995) Spatiotemporal distribution of the microphytobenthic biomass in intertidal flats of Tagus Estuary (Portugal). Hydrobiologia 301:93-104

Carpenter SR, Kitchell JF, Hodgson JR (1985) Cascading trophic interactions and lake productivity. Biosciences 35: 634-639

Connor MS, Teal JM, Valiela I (1982) The effect of feeding by mud snails, Ilyanassa obsoleta (Say), on the structure and metabolism of a laboratory benthic algal community. J Exp Mar Biol Ecol 65:29-45

Cox EJ (1995) Morphological variation in widely distributed diatom taxa. In: Proceedings of the 13th International Diatom Symposium. Biopress, Bristol, p 335-345

Cox EJ (1998) The identity and typification of some naviculoid diatoms (Bacillariophyta) from freshwater or brackish habitats. Phycologia 37:162-175

Decho AW (2000) Microbial biofilms in intertidal systems: an overview. Cont Shelf Res 20:1257-1273

de Deckere E, Tolhurst TJ, de Brouwer JFC (2001) Destabilization of cohesive intertidal sediments by infauna. Estuar Coast Shelf Sci 53:665-669

de Jong DJ, de Jonge VN (1995) Dynamics and distribution of microphytobenthic chlorophyll- $a$ in the Western Scheldt estuary (SW Netherlands). Hydrobiologia 311:21-30

Diez B, Pedros-Alio C, Marsh TL, Massana R (2001) Application of denaturing gradient gel electrophoresis (DGGE) to study the diversity of marine picoeukaryotic assemblages and comparison of DGGE with other molecular techniques. Appl Environ Microbiol 67:2942-2951

Dortch Q (1982) Effect of growth conditions on accumulation of internal nitrate, ammonium, aminoacids, and protein in three marine diatoms. J Exp Mar Biol Ecol 61:243-264

Estrada M, Henriksen P, Gasol JM, Casamayor EO, PedrosAlio C (2004) Diversity of planktonic photoautotrophic microorganisms along a salinity gradient as depicted by microscopy, flow cytometry, pigment analysis and DNAbased methods. FEMS Microbiol Ecol 49:281-293

Fenchel T, Kofoed LH (1976) Evidence for exploitative interspecific competition in mud snails (Hydrobiidae). Oikos 27: 367-376
Findlay RH, Watling L (1998) Seasonal variation in the structure of a marine benthic microbial community. Aquat Ecol $36: 23-30$

Ford RB, Honeywill C (2002) Grazing on intertidal microphytobenthos by macrofauna: Is pheophorbide $a$ a useful marker? Mar Ecol Prog Ser 229:33-42

Forster RM, Créach V, Sabbe K, Vyverman W, Stal LJ (2006) Biodiversity-ecosystem function relationship in microphytobenthic diatoms of the Westerschelde estuary. Mar Ecol Prog Ser 311:191-201

Goto N, Mitamura O, Terai H (2000) Seasonal variation in primary production of microphytobenthos at the Isshiki intertidal flat in Mikawa Bay. Limnology 1:133-138

Grasshoff K (1976) Methods of seawater analysis. Verlag Chemie, Berlin

Hamels I, Sabbe K, Muylaert K, Vyverman W (2004) Quantitative importance, composition, and seasonal dynamics of protozoan communities in polyhaline versus freshwater intertidal sediments. Microb Ecol 47:18-29

Haubois AG, Sylvestre F, Guarini JM, Richard P, Blanchard GF (2005) Spatio-temporal structure of the epipelic diatom assemblage from an intertidal mudflat in MarennesOleron Bay, France. Estuar Coast Shelf Sci 64:385-394

Heip CHR, Goosen NK, Herman PMJ, Kromkamp J, Middelburg JJ, Soetaert K (1995) Production and consumption of biological particles in temperate tidal estuaries. Oceanogr Mar Biol Annu Rev 33:1-149

Herlory O, Guarini JM, Richard P, Blanchard GF (2004) Microstructure of microphytobenthic biofilm and its spatio-temporal dynamics in an intertidal mudflat (Aiguillon Bay, France). Mar Ecol Prog Ser 282:33-44

Hillebrand H (2005) Light regime and consumer control of autotrophic biomass. J Ecol 93:758-769

Hillebrand H, Durselen C, Kirschtel D, Pollingher U, Zohary T (1999) Biovolume calculation for pelagic and benthic microalgae. J Phycol 35:403-424

Kromkamp J, Peene J, Vanrijswijk P, Sandee A, Goosen N (1995) Nutrients, light and primary production by phytoplankton and microphytobenthos in the eutrophic, turbid Westerschelde Estuary (the Netherlands). Hydrobiologia 311:9-19

Lawley B, Ripley S, Bridge P, Convey P (2004) Molecular analysis of geographic patterns of eukaryotic diversity in Antarctic soils. Appl Environ Microbiol 70:5963-5972

Lomas MW, Gilbert PM (1999) Temperature regulation of nitrate uptake: a novel hypothesis about nitrate uptake and reduction in cool-water diatoms. Limnol Oceanogr 44: 556-572

Ludwig W, Strunk O, Westram R, Richter L and 28 others (2004) ARB: a software environment for sequence data. Nucleic Acids Res 32:1363-1371

Magurran AE (1988) Ecological diversity and its measurement. Princeton University Press, Princeton, NJ

Mann DG (1994) Auxospore formation, reproductive plasticity and cell structure in Navicula ulvacea and the resurrection of the genus Dickieia (Bacillariophyta). Eur J Phycol 29: 141-157

Massana R, Guillou L, Diez B, Pedros-Alio C (2002) Unveiling the organisms behind novel eukaryotic ribosomal DNA sequences from the ocean. Appl Environ Microbiol 68: $4554-4558$

Massieux B, Boivin MEY, van den Ende FP, Langenskiold J and 5 others (2004) Analysis of structural and physiological profiles to assess the effects of $\mathrm{Cu}$ on biofilm microbial communities. Appl Environ Microbiol 70:4512-4521

Medlin L, Kaczmarska I (2004) Evolution of the diatoms. V. Morphological and cytological support for the major 
clades and a taxonomic revision phycologia. Phycologia 43: 245-270

Meire P, Ysebaert T, Van Damme S, Van den Bergh E, Maris T, Struyf E (2005) The Scheldt estuary: a description of a changing ecosystem. Hydrobiologia 540:1-11

Middelburg JJ, Barranguet C, Boschker HTS, Herman PMJ, Moens T, Heip CHR (2000) The fate of intertidal microphytobenthos carbon: an in situ C-13-labeling study. Limnol Oceanogr 45:1224-1234

Mundree S, Perissinotto R, Nozais C (2003) Seasonal variations in the vertical distribution of benthic microalgae in the upper sediment of the Mdloti Estuary, South Africa. Bot Mar 46:323-331

Muyzer G, Dewaal EC, Uitterlinden AG (1993) Profiling of complex microbial-populations by denaturing gradient gel-electrophoresis analysis of polymerase chain reaction-amplified genes-coding for $16 \mathrm{~s}$ ribosomal-RNA. Appl Environ Microbiol 59:695-700

Oppenheim DR (1991) Seasonal changes in epipelic diatoms along an intertidal shore, Berrow Flats, Somerset. J Mar Biol Assoc UK 71:579-596

Rasmussen MB, Henriksen K, Jensen A (1983) Possible causes of temporal fluctuations in primary production of the microphytobenthos in the Danish Wadden Sea. Mar Biol 73: 109-114

Rijstenbil JW (2003) Effects of UVB radiation and salt stress on growth, pigments and antioxidative defence of the marine diatom Cylindrotheca closterium. Mar Ecol Prog Ser 254: $37-47$

Round F, Crawford R, Mann D (1990) The diatoms — biology \& morphology of the genera. Cambridge University Press

Sabbe K (1993) Short-term fluctuations in benthic diatom numbers on an intertidal sandflat in the Westerschelde Estuary (Zeeland, the Netherlands). Hydrobiologia 269: $275-284$

Sabbe K (1997) Systematics and ecology of intertidal benthic diatoms of the Westerschelde estuary (The Netherlands). $\mathrm{PhD}$ thesis, Universiteit Gent

Savin MC, Martin JL, LeGresley M, Giewat M, Rooney-Varga $\mathrm{J}$ (2004) Plankton diversity in the Bay of Fundy as measured by morphological and molecular methods. Microb Ecol 48: $51-65$

Snoeijs P, Busse S, Potapova M (2002) The importance of diatom cell size in community analysis. J Phycol 38:265-272

Soetaert K, Vincx M, Wittoeck J, Tulkens M (1995) Meiobenthic distribution and nematode community

Editorial responsibility: Staffan Kjelleberg,

Sydney, New South Wales, Australia structure in five European estuaries. Hydrobiologia 311:185-206

Stal LJ (2003) Microphytobenthos, their extracellular polymeric substances, and the morphogenesis of intertidal sediments. Geomicrobiol J 20:463-478

Stoeck T, Epstein S (2003) Novel eukaryotic lineages inferred from small-subunit rRNA analyses of oxygen-depleted marine environments. Appl Environ Microbiol 69: 2657-2663

ter Braak CJF, Smilauer P (1998) Canoco reference manual and user's guide to Canoco for Windows: software for canonical community ordination. Microcomputer Power, Ithaca, NY

ter Braak CJF, Smilauer P (2002) Canoco reference manual and CanoDraw for Windows user's guide: software for canonical community ordination (Version 4.5). Microcomputer Power, Ithaca, NY

Thornton DCO, Dong LF, Underwood GJC, Nedwell DB (2002) Factors affecting microphytobenthic biomass, species composition and production in the Colne Estuary (UK). Aquat Microb Ecol 27:285-300

Underwood GJC (1994) Seasonal and spatial variation in epipelic diatom assamblages in the Severn estuary. Diatom Res 9:451-472

Underwood GJC, Kromkamp J (1999) Primary production by phytoplankton and microphytobenthos in estuaries. Adv Ecol Res 29:93-153

Underwood GJC, Provot L (2000) Determining the environmental preferences of four estuarine epipelic diatom taxa: growth across a range of salinity, nitrate and ammonium conditions. Eur J Phycol 35:173-182

Underwood GJC, Phillips J, Saunders K (1998) Distribution of estuarine benthic diatom species along salinity and nutrient gradients. Eur J Phycol 33:173-183

van Spaendonk JCM, Kromkamp JC, de Visscher PRM (1993) Primary production of phytoplankton in a turbid coastal plain estuary, the Westerschelde (the Netherlands). Neth J Sea Res 31:267-279

Vos PC, Dewolf H (1993) Diatoms as a tool for reconstructing sedimentary environments in coastal wetlands. Hydrobiologia 269:285-296

Worm B, Lotze HK, Hillebrand H, Sommer U (2002) Consumer versus resource control of species diversity and ecosystem functioning. Nature 417:848-851

Ysebaert T, Fettweis M, Meire P, Sas M (2005) Benthic variability in intertidal soft-sediments in the mesohaline part of the Schelde estuary. Hydrobiologia 540:197-216

Submitted: October 9, 2006; Accepted: February 27, 2007

Proofs received from author(s): April 30, 2007 